\title{
Хірургічне лікування та профілактика параколостомічних гриж у хворих похилого та старечого віку
}

\begin{abstract}
Мета роботи: покращити результати хірургічного лікування параколостомічних гриж у хворих похилого та старечого віку за рахунок впровадження лапароскопічних способів лікування.

Матеріали і методи. Хірургічне лікування виконували за 3 способами: герніопластика із залишенням колостоми на колишньому місці - 20 (29,0 \%) хворих; герніопластика з переміщенням колостоми на нове місце - 36 (52,2 \%); у 25 (36,2\%) - малоінвазивні методи. 3-м (4,3 \%) пацієнтам були застосовані аутопластичні; 66 (95,7 \%) - алопластичні методи, де в 4-х (5,8 \%) - за методом onlay, 40 (58,0 \%) - за методом sublay, 17 (24,6 \%) - лапароскопічна герніопластика за удосконаленим методом та 8 (11,6 \%) лапароскопічно-асистованим способом.

Результати досліджень та їх обговорення. Серед 69 хворих ми спостерігали прямопропорційну залежність інтенсивності розвитку злукового процесу не від тривалості грижоносіння, а від розмірів грижових воріт. 24 хворим було виконано профілактичне використання протезної сітки при формуванні стоми. Місцеві гнійно-запальні ускладнення мали місце в 6 (8,7 \%) випадках, де в 1-го (1,4 \%) пацієнта з аутопластичним методом герніопластика та у 5 (7,2 \%) - при застосуванні алопластичного методу. Рецидивів захворювання не спостерігали. Хворим похилого та старечого віку при виведенні колостоми рекомендовано превентивне алопротезування. Найкращі результати були отримали при алогерніопластиці з реконструкцією колостоми на інше місце та при лапароскопічній грижопластиці. 7 (10,1 \%) хворим адгезіолізис, виділення дистального та низведення проксимального відділів стомованої кишки вдалось виконати лапароскопічно. 8 (11,6 \%) хворим із дефектом W виконали лапароскопічну алогерніопластику композитною сіткою за внутрішньоочеревинною методикою IPOМ.
\end{abstract}

Ключові слова: параколостомічна грижа; грижопластика; хворі похилого та старечого віку.

Постановка проблеми та аналіз останніх досліджень та публікацій. На сьогодні в усьому світі зростає кількість виявлених захворювань на онкологічну патологію, в тому числі товстої кишки, яку в більшості виявляють в людей похилого віку, що, у свою чергу, потребує оперативного лікування, яке закінчується виведенням колостоми $[1,3]$. Виникнення дефекту в ділянці колостоми у хворих даної вікової категорії пов'язано з вираженою віковою слабкістю м'язово-апоневротичних шарів черевної стінки, а також супутніми захворюваннями (хронічне обструктивне захворювання легень, ожиріння, аденома передміхурової залози тощо), що призводять до постійного підвищення внутрішньочеревного тиску [1, 7]. Хірургічна техніка також може бути фактором, що призводить до збільшення або зниження ризику грижі [18].

Таким чином, ряд авторів вважає розвиток параколостомальної грижі (ПКСГ) у даної вікової категорії є практично неминучим [9].

Також зазначають, що для даної категорії до 2,5 \% перебіг захворювання ускладнюється защемленням [2].

Зазвичай розміри ПКСГ визначають за классификацією J. P. Chevrel, A. M. Rath (SWRclassification, 1999p.), але вважають іï недостатньою. Тому закордонні хірурги користуються кла- сифікацією Moreno-Matias [2009] та Seо [2011], де виділяють такі категорії:

0 - КТ зображення нормальне, в цьому випадку очеревина рухається зі стінкою кишки, утворюючи стому без мішка;

Іа - кишка, що утворює колостому з мішком менше 5 см;

Ib - кишка, що утворює колостому з мішком, більше 5 см;

II - мішок, що містить сальник;

III - мішок, що містить кишкову “петлю”, яка знаходиться у стомі

За даними Gil [2011], на основі фізичного обстеження пацієнта можна виділити такі категорії:

I - мала та ізольована ПКСГ;

II - невелика ПКСГ без деформації передньої стінки живота;

III - ізольована, велика ПКСГ з деформацією передньої стінки живота;

IV - велика ПКСГ із співіснуючою серединною післяопераційною грижою, з деформацією передньої стінки живота.

Класифікація ЄБС (ЄГС) Європейського грижового товариства [2014]: отримана з рентгенологічних результатів та клінічного обстеження пацієнта.

I - діаметром менше 5 см, що не має співіснуючої післяопераційної грижі; 
II - діаметром менше 5 см, включно співіснуючу післяопераційну грижу;

III - більше 5 см в діаметрі без співіснуючої післяопераційної грижі;

IV - більше 5 см в діаметрі, включно співіснуючу післяопераційну грижу [18].

Існують класифікації, засновані на розташуванні екстеріоризованого вмісту, а також за типом вмісту грижового мішка (сальник, тонка кишка). Але, як визнає більшість науковців, практичність цих всіх класифікацій обмежена [11].

Виходячи з літературних джерел аутопластичний спосіб лікування ПКСГ вперше був описаний у 1965 році Thorlakson, який виконувався із застосуванням перистомального розрізу до 5 см від слизово-шкірного переходу до усунення апоневротичного дефекту [18]. Рецидив захворювання при цьому склав від 46 до 100 \% [4, 10]. Вважають, що даний спосіб слід застосовувати у випадках ранніх гриж. У цих ситуаціях ймовірно, що апоневротична слабкість в ділянці стоми на даний період мінімальна [5, 13].

Найбільш поширеним способом лікування ПКСГ є переміщення стоми на іншу ділянку черевної стінки. Складається з виконання лапаротомії та розміщення кишкового сегмента на новому місці передньої черевної стінки. Проте ряд авторів вказує, що у цього хірургічного методу більше недоліків, ніж переваг, а саме: релапаротомія (що може призвести до рецидиву грижі); створення нового дефекту в черевній стінці, її підвищене інфікування [10].

Застосування алопластики при лікуванні ПКСГ вперше описано в 1977 році Розіном та Бонарді, які використовували поліетиленову сітку у 7 пацієнтів. Сітка розміщувалася навколо товстої кишки і рецидивів, за даними авторів, у цій групі не було [8]. В 1982 році описали перфорацію сіткою кишки з наступним розвитком гнійно-запальних ускладнень [8, 18].

Відтоді опубліковано багато повідомлень про частоту рецидивів від 14 до 43 \%, включно непрохідність кишечника у 9 \%, пролапс у 3 \%, інфекцію рани у 3 \%, нориці у 3 \% [14, 15$]$.

При внутрішньоочеревинному розміщенні імпланту за технікою Sugarbaker (1985), як сам автор вважає, рецидив менш вірогідним, оскільки немає необхідності в розсіченні м’язів [13].

Перше лапароскопічне лікування ПКСГ було опубліковано в 1998 році Porcheron, де апоневротичний дефект закрили ПТФЕ-протезом (політетрафторетилен) [6]. У варіанті Voitk, модифікованому Sugarbaker, протез не потрібно різати і може покривати грижовий дефект способом, подібним до описаного при “відкритому” методі. При цьо- му протез накладають безпосередньо на грижовий дефект, яким “стискають” товсту кишку [16]. Довгострокові результати із застосуванням лапароскопічних методів ще не відомі, однак негативні безпосередні результати захворювання (біль, інфекційні ускладнення) начебто зменшуються. Частота рецидивів після лапароскопічного відновлення оцінюється між 0 і 40 \% [18]. У порівняльному дослідженні в клініці Майо та опублікованому Mc Lemore et al., 39 пацієнтів, які перенесли “відкрите” лікування ПКСГ, порівняли з 19, яким застосували лапароскопічний спосіб. Час операції був більш тривалішим при лапароскопічних операціях, але тривалість перебування в стаціонарі та частота інфекційних ускладнень була однаковою для обох груп, що свідчить про відсутність значної переваги лапароскопічної методики [17]. Отже, можна стверджувати, що на даний час не існує ідеального методу, який може бути рекомендований як спосіб хірургічного лікування ПКСГ у хворих похилого та старечого віку (ХПСВ).

Мета роботи: покращити результати хірургічного лікування ПКСГ у хворих похилого та старечого віку за рахунок впровадження лапароскопічних способів лікування.

Матеріали і методи. В окрему групу виділили 69 (100,0 \%) хворих прооперованих з ПКСГ. За статтю чоловіки становили 39 (56,2 \%) осіб, жінки - 20 (29,0 \%). Усі хворі були старшої вікової категорії, вік хворих коливався від 60 до 93 років, середній вік становив $(76,0 \pm 1,5)$ року.

ПКСГ, за класификацією J.P. Chevrel, A.M. Rath (SWR-classification, 1999 р.), малого розміру (W ${ }_{1}$ ) мала місце у 6 (8,7 \%) випадках, середнього розміpy $\left(\mathrm{W}_{2}\right)$ - у $40(57,8 \%)$ пацієнтів, великого $\left(\mathrm{W}_{3}\right)-$ у 15 (81,2 \%), гігантського $\left(\mathrm{W}_{4}\right)$ - у 4 (5,8 \%). Невправимі грижі мали 56 (89,7 \%) особи, із них у 5 (7,2 \%) - симптоми защемлення.

В усіх хворих цієї вікової категорії мала місце поєднана супутня патологія: атеросклеротичний і постінфарктний кардіосклероз - у 69 (100,0 \%) випадках; ХОЗЛ - у 48 (69,6 \%); ожиріння - у 38 (55,1 \%); цукровий діабет - у 18 (26,1 \%); церебросклероз - у 17 (24,6 \%).

Із анамнезу захворювання хворим були виконані такі операції: резекція сигморектальної ділянки кишки $з$ виведенням однодульної сигмостоми - була виконана 36 (52,2 \%) хворим; резекція сигмоподібної кишки з виведенням дводульної колостоми - 6 (8,7 \%); лівобічна геміколектомія 3 виведенням трансверзостоми в лівому підребер’ї - 20 (29,0%), після резекції поперечно-ободової кишки з виведенням цекостоми - 6 (8,7\%). 


\section{З ДОСВІДУ РОБОТИ}

Хірургічне лікування ПКСГ виконували за 3 методиками: герніопластика (ГП) із залишенням колостоми на колишньому місці, що було виконано 20 (29,0%) хворим; ГП з переміщенням колостоми на нове місце - 36 (52,2 \%) особам; 13 (18,2 \%) - малоінвазивні методи. Тільки 3-м (4,3 \%) пацієнтам були застосовані аутопластичні; 66 (95,7 \%) - алопластичні методи, де в 4-х (5,8 \%) - за методом onlay, 40 (57,8 \%) - за методом sublay, 17 (24,6 \%) - лапароскопічна ГП за удосконаленим методом із залишенням стоми на колишньому місці та 8 (11,6 \%) - лапароскопічноасистованим способом. Середня тривалість даного способу лапароскопічної ГП склала $(65,5 \pm 5,5)$ хвилин. При “відкритих” способах $-45,5 \pm 5,5$.

Результати досліджень та їх обговорення. У всіх 69 (100\%) пацієнтів клінічним проявом було наявність випинання в ділянці стоми з болем або без нього. Здуття живота і нудота у 60 (87,0 \%) хворих. У 10-ти (14,5 \%) випадках термінальний відділ стоми був стенозований, при цьому виникала клінічна картина часткової механічної кишкової непрохідності. У 24 (34,8 \%) хворих спостерігали тенденцію до її защемлення, вихід товстої кишки $з$ перегином кишки та стенозом просвіту, нориці, наявність евентрації, інші порушення iї функції.

При аутопластиці починали з розрізу шкіри та підшкірної клітковини по колу навколо грижового мішка (ГМ). ГМ виділяли із зрощень до апоневрозу і розкривали його. Вміст ГМ також звільняли від зрощень і занурювали в черевну порожнину. ГМ відсікали, а очеревину по краю грижових воріт підшивали окремими чи вікриловими швами до виведеної петлі ободової кишки. Після чого вже апоневроз звільняли від зрощень та рубців і підшивали його також до виведеної кишки. Шкіру зашивали тільки після дренування підшкірної порожнини. Цей спосіб був застосований у 2-х (2,9\%) хворих.

При алопластичних методах ГП застосовували 3 способи.

1-й спосіб алогерніопластики (без переміщення колостоми). ГМ розкривали розрізом очеревини на межі з виведеною кишкою звільняючи її від зрощень. Звільняли від рубців і зрощень стомований відділ ободової кишки, внаслідок чого його довжина збільшувалась, що давало можливість сформувати нову колостому. ГМ відсікали, за можливістю частково при відсутності запальних процесів у ньому, краї його очеревини підшивали окремими швами до виведеної кишки на $\approx 3,0$ см нижче від стомального отвору. Потім очеревину відділяли від задньої стінки апоневрозу черевної стінки не менше ніж на 3,0 см по периметру. Якщо виділити очеревину не пошкоджуючи її цілісність не вдавалося, то розсікали апоневроз внутрішнього косого м'яза та відділяли від м'яза на вказану відстань навколо стоми, протезну сітку розміщували преперитонеально (Stoppa). Протез фіксували по периметру трансабдомінальними швами для уникнення додаткової травматизації та інфікування підшкірної клітковини. Отвір в імплантаті не вирізали, а з латерального боку розсікали його до середини на відстань не менше ніж 5-6 см. У цей розріз розміщували кишку, формували стому під контролем пальця в просвіті кишки, підшиваючи до неї очеревину апоневроз, протез, м’яз та шкіру одним швом, де довжина “кроку” до наступного шва становила не більше ніж 1,0 см. Стежили, щоб не було контакту ППС зі стінкою кишки, “страхувалися” дублікатурою залишку грижового мішка. Обов’язково над протезом через окремий розріз ставили дренаж.

2-й спосіб алогерніопластики (реконструкція колостоми на інше місце). Цей спосіб застосовували при ПКСГ значних розмірів, де навколишній апоневроз навколо стоми був атрофічно-дегенеративно змінений з контрактурою м'язів і з їх рубцевим переродженням, що були не придатні для будь-якої пластики. ГМ та низведення стомального відділу товстої кишки виконували описаним вище способом. Потім після висічення рубцево-змінених відділів та старої колостоми, відступивши від цього дефекту на 7 - 10 см в краніальному чи в каудальному напрямі після мобілізації на достатню довжину стомального відділу товстої кишки, створювали “тунель” у передочеревинному просторі, де на кінці цього “тунеля” розсікали шкіру і виводили стомальний відділ товстої кишки у новий сформований отвір черевної стінки. Потім проводили алопластику дефекту черевної стінки на місці колостоми і грижових воріт. При даному способі, як правило, виконували превентивне протезування.

Встановлені недоліки: спосіб передбачає травматизацію всіх шарів черевної стінки; не виключений контакт поліпропіленового імплантату 3 вивідною кишкою з подальшим розвитком адгезивно-запальних процесів у ній; незважаючи на наявність дренування зберігалася ймовірність нагноєння післяопераційної рани. Все це стало передумовою для застосування менш інвазивного 3-го способу ГП - лапароскопічної ГП.

При даному 3-му способі виконували зведення країв грижових воріт без звуження просвіту виведеної кишки; краї листків поліпропіленового протеза навколо стомального відділу товстої 
кишки повинні бути без контакту з нею. Це досягалося таким чином: протез був достатнім за розміром (не менше ніж 5,0 см від краю грижових воріт); виконували розріз протеза з латерального боку для розташування в ньому ділянки вивідної кишки; фіксували протез “кисетним” швом, кінці якого трансабдомінально виводили наззовні з латерального боку “стоми” через насічку на шкірі, краї листків протеза фіксували дужками навколо вивідної кишки, відступивши від краю грижових воріт $\approx$ на 0,5 см; по краю грижових воріт фіксували ділянки ГМ чи очеревини, відмежовуючи таким чином поліпропіленовий імплантат від стінки вивідної товстої кишки; виконували ліквідацію грижових воріт під контролем пальця в просвіті кишки шляхом затягнення екстракорпорально “кисетного” шва через насічку на шкірі з латерального боку від стоми, вузол якого фіксували надапоневротично. Цей спосіб виконували хворим із дефектами розміром $\mathrm{W}_{1}-\mathrm{W}_{2}$. Відстежили прямопропорційну залежність інтенсивності розвитку злукового процесу не від тривалості грижоносіння, а від розмірів грижових воріт. 7 (10,1 \%) хворим адгезіолізіс, виділення дистального та низведення проксимального відділів стомованої кишки вдалось виконати лапароскопічно. 8 (11,6 \%) хворим із дефектом $\mathrm{W}_{3}$ виконали лапароскопічну алогерніо-

\section{СПИСОК ЛІТЕРАТУРИ}

1. Воровський О. О. Застосування малоінвазивних методів при хірургічному лікуванні параколостомічних гриж у хворих похилого віку / О. О. Воровський // Вестник неотложной и восстановительной медицины. - 2013. - № 3 (14). - С. 321-324.

2. Воровський О. О. Лапароскопічна герніопластика у лікуванні защемлених гриж у хворих похилого та старечого віку / О. О. Воровський, В. О. Шапринський, Д. А. Яцков, Н. Закі // Шпитальна хірургія. Журнал імені Л. Я. Ковальчука. - 2016. - № 2. - С. 81-84.

3. Алогерніопластика параколостомічних гриж / В. І. Мамчич, В. Г. Яцентюк, А. В. Мусієнко, П. В. Коломієць // Матеріали XXII з'їзду хірургів України [“IV міжнародні пироговські читання”]. - 2010. - Т. 2. - С. 227-228.

4. Incidence and risk factors for parastomal bulging in patients with ileostomy or colostomy: a register-based study using data from the Danish Stoma Database Capital Region / R. M. Andersen, T. W. Klausen, A. K. Danielsen [et al.] // Colorectal Dis. - 2018. - Vol. 20. - P. 331-340.

5. Parastomal hernia: a growing problem with new solutions / C. T. Aquina, J. C. Iannuzzi, C. P. Probst [et al.] // Dig. Surg. 2014. - Vol. 31. - P. 366-376.

6. Outcome of parastomal hernia repair with and without midline laparotomy / M. K. Baig, J. A. Larach, S. Chang [et al.] // Tech. Coloproctol. - 2006. - Vol. 10. - P. 282-286.

7. The prevalence of ostomy-related complications 1 year after ostomy surgery: a prospective, descriptive, clinical study / E. Carlsson, J. Fingren, A. M. Hallen [et al.] // Ostomy Wound Manage. - 2016. - Vol. 62. - P. 34-48. пластику композитною сіткою за внутрішньоочеревинною методикою IРОМ.

24 хворим було виконано профілактичне використання протезної сітки при формуванні стоми, яким виконали колостомію з постійним кінцем в елективній хірургії раку кишечника, де в 15 (21,7 \%) протягом 4-6 років ПКСГ не спостерігали. В 9 (13,0 \%) випадках мали проблему в спостережені, що не охоплювали трьох років після операції.

В ранньому післяопераційному періоді місцеві гнійно-запальні ускладнення мали місце в 6 $(8,7 \%)$ випадках, де в 1-го (1,4 \%) пацієнта з аутопластичним методом ГП та у 5 (7,2 \%) - при застосуванні алопластичних. Із них сероми - 3 (4,3\%) та нагноєння післяопераційної рани - $1(1,4 \%)$ у групі хворих зі способом “залишенням колостоми на колишньому місці”; лігатурна нориця - 1 (1,4%). При лапароскопічній ГП з розробленою методикою дані ускладнення не спостерігались. Рецидивів захворювання не спостерігали.

Висновки. Отже, при лікуванні ПКСГ найкращі результати були отримані при алогерніопластиці з реконструкцією колостоми на інше місце та лапароскопічній грижопластиці. Хворим похилого та старечого віку при виведенні колостоми рекомендовано превентивне алопротезування.

8. Parastomal and incisional hernia following laparoscopic/open abdominoperineal resection: is there a real difference? / P. Ihnát, L. Tulinský, T. Jonszta [et al.] // Surg. Endosc. - 2019. - Vol. 1. - P. 22-26.

9. Living with a parastomal bulge - patients' experiences of symptoms / M. Krogsgaard, T. Thomsen, A. Vinther [et al.] // J. Clin. Nurs. - 2017. - Vol. 26. - P. 5072-5081.

10. Systematic review and meta-analysis of extraperitoneal versus transperitoneal colostomy for preventing parastomal hernia / L. F. Kroese, G. H. de Smet, J. Jeekel [et al.] // Dis. Colon Rectum. - 2016. - Vol. 59. - P. 688-695.

11. Leslie D. The parastomal hernia / D. Leslie // Surg. Clin. North Am. - 1984. - Vol. 64. - P. 407-405.

12. Laparoscopic parastomal hernia repair using a nonslit mesh technique / G. J. Mancini, D. A. McClusky, L. Khaitan [et al.] // Surg. Endosc. - 2007. - Vol. 21. - P. 1487-1491.

13. Morris-Stiff G. J. The outcomes of nonabsorbable mesh placed within the abdominal cavity: literature review and clinical experience / G. J. Morris-Stiff, L. E. Hughes // J. Am. Coll. Surg. - 1998. - Vol. 186. - P. 352-367.

14. European Hernia Society classification of parastomal hernias / M. Śmietański, M. Szczepkowski, J. A. Alexandre [et al.] // Hernia. - 2014. - Vol. 18. - P. 1-6.

15. Styliński R. Parastomal hernia - current knowledge and treatment / R. Styliński, A. Alzubedi, S. Rudzki // Wideochir Inne Tech Maloinwazyjne. - 2018. - Vol. 13. - P. 1-8.

16. A 5-year clinical experience with single- staged repairs of infected and contaminated abdominal wall defects utilizing 
biologic mesh / M. J. Rosen, D. M. Krpata, B. Ermlich [et al.] // Ann. Surg. - 2013. - Vol. 257. - P. 991-996.

17. Rubin M. S. Parastomal hernia. Is stoma relocation superior to fascial repair? / M. S. Rubin, D. J. Jr. Schoetz, J. B. Matthews //
Arch. Surg. - 1994. - Vol. 129. - P. 413-418.

18. Techagumpush A. Update in parastomal hernia / A. Techagumpush, S. Udomsawaengsup // Ann. Laparosc. Surg. - 2019. - Vol. 4. - P. 75.

\section{REFERENCES}

1. Vorovskyi, O.O. (2013). Zastosuvannia maloinvazyvnykh metodiv pry khirurhichnomu likuvanni parakolostomistychnykh hryzh u khvorykh pokhyloho viku [Application of minimally invasive methods in the surgical treatment of paracolostomy hernias in elderly patients]. Vestnik neotlozhnoy i vosstanovitelnoy meditsyny - Bulletin of Emergency and Recovery Medicine, 3 (14), 321-324 [in Ukrainian].

2. Vorovskyi, O.O., Shaprynskyi, V.O., Yatskov, D.A., \& Zaki, N. (2016). Laparoskopichna hernioplastyka u likuvanni zashchemlenykh hryzh u khvorykh pokhyloho ta starechoho viku [Laparoscopic hernioplasty in the treatment of constricted hernias in senile and elderly patients]. Shpytalna khirurhiia. Zhurnal imeni L. Ya. Kovalchuka - Hospital Surgery. Journal named after L.Ya. Kovalchuk, 2, 81-84 [in Ukrainian].

3. Mamchych, V.I., Yatsentiuk, V.H., Musiienko, A.V., \& Kolomiiets, P.V. (2010). Alohernioplastyka parakolostomichnykh hryzh [Allogernioplasty of paracolostomy hernias]. Materialy XXII zizdu khirurhiv Ukrainy - Materials of XXII Congress of Surgeons of Ukraine, 2, 227-228 [in Ukrainian].

4. Andersen, R.M., Klausen, T.W., \& Danielsen, A.K. (2018). Incidence and risk factors for parastomal bulging in patients with ileostomy or colostomy: a register-based study using data from the Danish Stoma Database Capital Region. Colorectal Dis., 20, 331-340. 5. Aquina, C.T., Iannuzzi, J.C., \& Probst, C.P. (2014). Parastomal hernia: a growing problem with new solutions. Dig. Surg., 31, 366-376.

6. Baig, M.K., Larach, J.A., \& Chang, S. (2006). Outcome of parastomal hernia repair with and without midline laparotomy. Tech. Coloproctol., 10, 282-286.

7. Carlsson, E., Fingren, J., \& Hallen, A.M. (2016). The prevalence of ostomy-related complications 1 year after ostomy surgery: a prospective, descriptive, clinical study. Ostomy Wound Manage, 62, 34-48.
8. Ihnát, P., Tulinský, L., \& Jonszta, T. (2019). Parastomal and incisional hernia following laparoscopic/open abdominoperineal resection: is there a real difference? Surg. Endosc., 1, 22-26.

9. Krogsgaard, M., Thomsen, T., \& Vinther, A. (2017). Living with a parastomal bulge - patients' experiences of symptoms. $J$. Clin. Nurs., 26, 5072-5081.

10. Kroese, L.F., de Smet, G.H., \& Jeekel, J. (2016). Systematic review and meta-analysis of extraperitoneal versus transperitoneal colostomy for preventing parastomal hernia. Dis. Colon. Rectum, 59, 688-695.

11. Leslie, D. (1984). The parastomal hernia. Surg. Clin. North Am., 64, 407-405.

12. Mancini, G.J., McClusky, D.A., \& Khaitan, L. (2007). Laparoscopic parastomal hernia repair using a nonslit mesh technique. Surg. Endosc., 21, 1487-1491.

13. Morris-Stiff, G.J., \& Hughes, L.E. (1998). The outcomes of nonabsorbable mesh placed within the abdominal cavity: literature review and clinical experience. J. Am. Coll. Surg., 186, 352-367. 14. Śmietański, M., Szczepkowski, M., \& Alexandre, J.A. (2014). European Hernia Society classification of parastomal hernias. Hernia, 18, 1-6.

15. Styliński, R., Alzubedi, A., \& Rudzki, S. (2018). Parastomal hernia - current knowledge and treatment. Wideochir Inne Tech Maloinwazyjne, 13, 1-8.

16. Rosen, M.J., Krpata, D.M., \& Ermlich, B. (2013). A 5-year clinical experience with single- staged repairs of infected and contaminated abdominal wall defects utilizing biologic mesh. Ann. Surg., 257, 991-996.

17. Rubin, M.S., Schoetz, D.J. Jr., \& Matthews, J.B. (1994). Parastomal hernia. Is stoma relocation superior to fascial repair? Arch. Surg., 129, 413-418.

18. Techagumpush, A., \& Udomsawaengsup, S. (2019). Update in parastomal hernia. Ann. Laparosc. Surg., 4, 75.

Отримано 29.10.2019

\section{SURGICAL TREATMENT AND PREVENTION OF PARACOLOSTOMY HERNIA IN PATIENTS OF THE ELDERLY AND SENILE AGE}

The aim of the work: to improve results of surgical treatment of paracolostomy hernias in patients of elderly and senile age on account of the introduction of laparoscopic methods of treatment.

Materials and Methods. Surgical treatment was performed by 3 methods: hernioplasty with colostomy left in the former place -20 (29.0 \%) patients; hernioplasty with the movement of colostomy on new place - 36 (52.2 \%); in 25 (36.2 \%) - minimally invasive methods. 3 (4.3\%) patients were administered autoplastic; 66 (95.7 \%) - alloplastic methods, where in the 4th (5.8 \%) - by the onlay method, 40 (58.0 \%) - by the sublay method, 17 (24.6\%) - laparoscopic hernioplasty by the advanced method and 8 (11.6 \%) were laparoscopically assisted. 
Results and Discussion. Among 69 patients, we found a direct proportional dependence of the intensity of the development of the connective process, not on the length of herniation, but on the size of the hernia gates. 24 patients underwent prophylactic use of prosthetic mesh when forming of stoma. Local pyo-inflammatory complications had a place in 6 (8.7 \%) cases, where in 1 (1.4 \%) patient with autoplastic method hernioplasty and 5 (7.2 \%) - when applying aloplastic method. No recurrence of the disease was observed. Elderly and senile patients when forming colostomy are advised preventive aloprosthetics. The best results were obtained with allohernioplasty with reconstruction of the colostomy to another location and with laparoscopic hernioplasty. 7 (10.1\%) patients with adhesiolysis of the distal and lowering of the proximal part of the gut were able to perform laparoscopically. 8 (11.6\%) patients with W3 defect performed laparoscopic allohernioplasty composite mesh by intraperitoneal IPOM technique.

Key words: paracolostomy hernia; hernioplasty; patients of elderly and senile age.

\author{
В. А. ШАПРИНСКИЙ, О. О. ВОРОВСКИЙ, И. Н. САДИК
}

Винницкий национальный медицинский университет имени Н. И. Пирогова

\title{
ХИРУРГИЧЕСКОЕ.ЛЕЧЕНИЕ И ПРОФИЛАКТИКАПАРАКОЛОСТОМИЧЕСКИХГРЫЖ У БОЛЬНЫХ ПОЖИЛОГО И СТАРЧЕСКОГО ВОЗРАСТА
}

Цель работы: улучшить результаты хирургического лечения параколостомичных грыж у больных пожилого и старческого возраста за счет внедрения лапароскопических способов лечения.

Материалы и методы. Хирургическое лечение выполняли за 3 способами: герниопластика с оставлением колостомы на прежнем месте - 20 (29,0 \%) больных; герниопластики с перемещением колостомы на новое место - 36 (52,2 \%); у 25 (36,2 \%) - малоинвазивные методы. 3-м (4,3 \%) пациентам были применены аутопластичные; 66 (95,7 \%) - аллопластические методы, где 4-м (5,8 \%) - по методу onlay, 40 (58,0 \%) - по методу sublay, 17 (24,6 \%) - лапароскопическая герниопластика по усовершенствованным методом и 8 (11,6 \%) - лапароскопически-ассистованим способом.

Результаты исследований и их обсуждение. Среди 69 больных нами было установлено прямопропорциональную зависимость интенсивности развития спаечного процесса не от продолжительности грыженосительства, а от размеров грыжевых ворот. 24 больным было выполнено профилактическое использование протезной сетки при формуваннии стомы. Местные гнойно-воспалительные осложнения имели место у 6 (8,7 \%) случаях, где в 1-й (1,4 \%) пациента с аутопластичним методом герниопластики и у 5 (7,2%) - при применении аллопластического метода. Рецидивов заболевания не наблюдалось. Больным пожилого и старческого возраста при выводе колостомы рекомендуется превентивное аллопротезирование. Наилучшие результаты были получены при аллогерниопластике с реконструкцией колостомы на место и при лапароскопической грижепластике. 7 (10,1 \%) больным адгезиолизис, выделение дистального и низведение проксимального отделов стомированной кишки удалось выполнить лапароскопически. 8 (11,6 \%) больным с дефектом W3 выполнили лапароскопическую аллогерниопластику композитной сеткой по внутрибрюшинной методике IPOM.

Ключевые слова: параколостомическая грыжа; грыжепластика; больные пожилого и старческого возраста. 